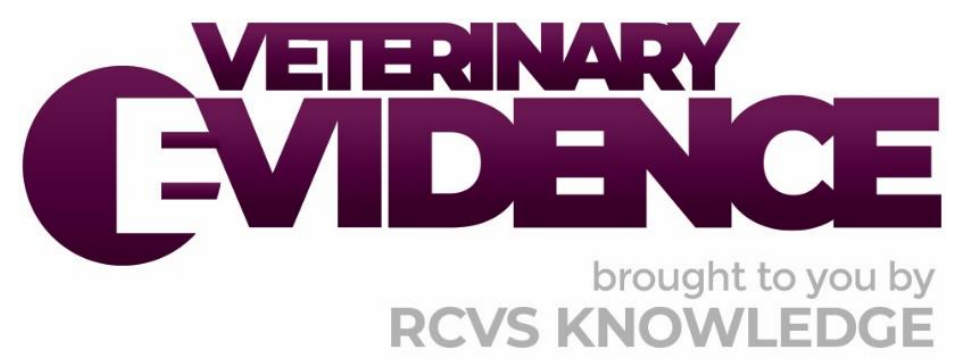

\title{
Treatment Duration With Steroid Monotherapy in Dogs With Steroid Responsive Meningitis-Arteritis
}

\author{
A Knowledge Summary by
}

Richard William Lawn BVSc, CertAVP, MRCVS ${ }^{1}$

\footnotetext{
${ }^{1}$ University of Bristol, Langford Vets, Langford, Somerset, BS40 5DU University of Bristol

*Corresponding Author (richard.lawn.2017@my.bristol.ac.uk)
}

ISSN: 2396-9776

Published: 28 Mar 2019

in: Vol 4, Issue 1

DOI: http://dx.doi.org/10.18849/ve.v4i1.221

Reviewed by: Simon Platt (DVM, BVM\&S, MRCVS, DACVIM (neurology), DECVN) and Conor O'Halloran (BVSc, MRCVS) 


\section{KNOWLEDGE SUMMARY}

\section{PICO question}

In dogs suspected of having steroid responsive meningitis-arteritis (SRMA), how long should immunosuppressive monotherapy with steroids be undertaken in order to achieve clinical resolution without relapse of clinical signs?

Clinical bottom line

Based on the currently available literature, steroid treatment using the protocol outlined in Lowrie et al. (2009) at a gradually tapering dose over a course of 6 months, appeared to lead to clinical remission in all cases, with a disease free post treatment interval of at least 6 months. However, further research is needed as there are currently three published papers with a low number of cases, so a definitive time course cannot be suggested until stronger evidence is available.

\section{Clinical Scenario}

You are presented with an 18-month-old female neutered Beagle with a history of anorexia and lethargy. On examination the dog shows cervical hyperesthesia and has a rectal temperature of $39.8^{\circ} \mathrm{C}$. Cerebral spinal fluid (CSF) analysis reveals a marked neutrophilic pleocytosis with elevated protein. A presumptive diagnosis of steroid responsive meningitis-arteritis (SRMA) is made, and you wish to start the dog on immunosuppressive monotherapy with steroids, however you are unsure as to how long the dog will require treatment to achieve clinical resolution and without relapse of clinical signs.

\section{Summary of the evidence}

\begin{tabular}{|c|c|}
\hline Tipold \& Jaggy (1994) & \\
\hline Population: & $\begin{array}{l}\text { Dogs with clinically confirmed SRMA referred to the Institute of } \\
\text { Animal Neurology, University of Berne, Brem-gartenstrasse, } \\
\text { Switzerland during an unspecified time frame }\end{array}$ \\
\hline Sample size: & 20 dogs \\
\hline Intervention details: & $\begin{array}{l}\text { - All cases were diagnosed based on clinical and neurological } \\
\text { examination, Complete Blood Count (CBC) and serum } \\
\text { biochemistry and CSF analysis. Some dogs had additional testing } \\
\text { including electromyography (EMG), electroencephalography } \\
\text { (EEG), myelography, Computed Tomography (CT) and } \\
\text { cisternography } \\
\text { - Dogs received prednisolone at } 4 \mathrm{mg} / \mathrm{kg} / \text { day. This was reduced to } \\
2 \mathrm{mg} / \mathrm{kg} / \text { day after } 2 \text { days and maintained for } 2 \text { weeks, followed } \\
\text { by } 1 \mathrm{mg} / \mathrm{kg} / \text { day for a further } 2 \text { weeks } \\
\text { - At this point dogs returned for examination to include CSF }\end{array}$ \\
\hline
\end{tabular}




\begin{tabular}{|c|c|}
\hline & $\begin{array}{l}\text { analysis, blood profile and EEG. These were repeated every } \\
\text { month since the beginning of the treatment for at least } 6 \\
\text { months } \\
\text { - As soon as neurological exam and CSF analysis were normal, the } \\
\text { prednisolone dose was reduced from } 1 \mathrm{mg} / \mathrm{kg} / \text { day until } 0.5 \\
\mathrm{mg} / \mathrm{kg} \text { every other day was achieved for } 6 \text { months. The } \\
\text { treatment was stopped when dogs presented clinically normal } \\
\text { with normal CSF and blood profile } \\
\text { - When pleocytosis was still detected, the same dosage was } \\
\text { maintained for } 6 \text { months }\end{array}$ \\
\hline Study design: & Prospective single centre case series \\
\hline Outcome studied: & $\begin{array}{l}\text { The diagnostic usefulness of ancillary testing and response to a } \\
\text { treatment protocol } \\
\text { Subjective: } \\
\text { - } \quad \text { Follow-up of dogs for up to } 4 \text { years after cessation of treatment } \\
\text { protocol } \\
\text { Objective: } \\
\text { - Occurrence of abnormalities in CSF analysis, blood profile and } \\
\text { EEG at monthly follow-ups }\end{array}$ \\
\hline $\begin{array}{l}\text { Main findings: } \\
\text { (relevant to PICO question): }\end{array}$ & $\begin{array}{l}\text { - } 12 / 20 \text { dogs that entered the study had no clinical signs following } \\
\text { the described treatment regimen and were free of neurological } \\
\text { signs for up to } 4 \text { years after treatment was stopped } \\
\text { - } 2 / 20 \text { improved but were still under treatment at the time of the } \\
\text { article's publication } \\
\text { - } 3 / 20 \text { cases relapsed after stopping the } 6 \text { month treatment } \\
\text { schedule } \\
\text { - One dog was euthanised } \\
\text { - The outcome was unknown in the two others }\end{array}$ \\
\hline Limitations: & 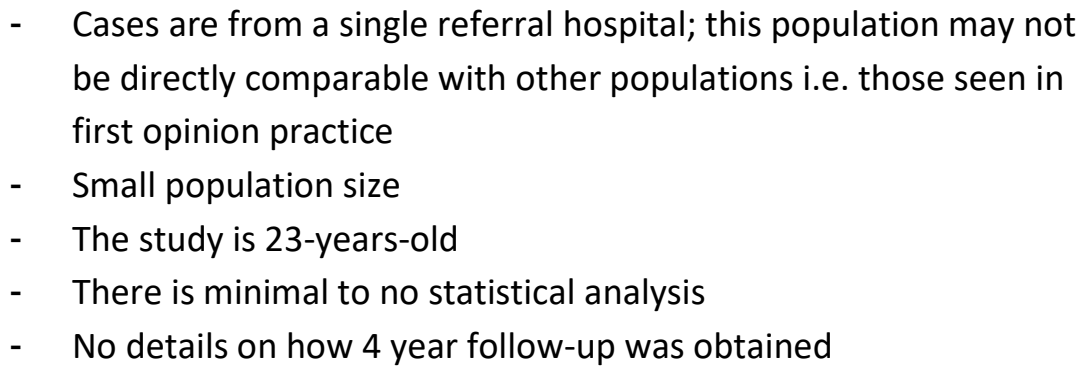 \\
\hline
\end{tabular}

\begin{tabular}{|r|l|}
\hline \multicolumn{2}{|l|}{ Cizinauskas, Jaggy \& Tipold (2000) } \\
\hline Population: & $\begin{array}{l}\text { Dogs with clinically confirmed SRMA referred to the Small Animal } \\
\text { Neurology Department, University of Bern, between March 1995 - } \\
\text { May 1997 }\end{array}$ \\
\hline Sample size: & 9 dogs \\
\hline Intervention details: & $-\quad$ All cases were diagnosed based on clinical and neurological \\
\hline
\end{tabular}




\begin{tabular}{|c|c|}
\hline & $\begin{array}{l}\text { examination, Complete Blood Count (CBC) and serum } \\
\text { biochemistry and Cerebral Spinal Fluid (CSF) analysis. Some dogs } \\
\text { had additional MRI and infectious disease PCR testing. } \\
\text { - All dogs were treated with a standard protocol initiated with } \\
\text { oral prednisolone at } 4 \mathrm{mg} / \mathrm{kg} / \mathrm{day} \text {. After } 2 \text { days this was reduced } \\
\text { to } 2 \mathrm{mg} / \mathrm{kg} / \text { day orally for } 2 \text { weeks, followed by } 1 \mathrm{mg} / \mathrm{kg} / \text { day } \\
\text { orally for } 1 \text { month. Dogs were rechecked at one to three month } \\
\text { intervals which included clinical examination, complete blood } \\
\text { count and biochemistry, and CSF tap } \\
\text { Once results of neurological and CSF examination were found to } \\
\text { be in normal range, prednisolone dose was reduced to half the } \\
\text { previous dosage until } 0.5 \mathrm{mg} / \mathrm{kg} \text { every alternate day was reached } \\
\text { If pleocytosis was present in CSF, initial dosage was maintained. } \\
\text { This therapeutic regimen was maintained for at least } 4 \text { months } \\
\text { until there were no clinical signs of SRMA and CSF tap and blood } \\
\text { results were normal in the two latest follow-up examinations } \\
\text { In dogs that relapsed, the prednisolone dose they were on at the } \\
\text { time was doubled. Dogs with frequent and severe relapses, } \\
\text { which did not respond to routine treatment (prednisolone } 1 \\
\text { mg/kg/day), received additional immunosuppressive therapy } \\
\text { with mycophenolate mofetil at } 20 \mathrm{mg} / \mathrm{kg} \text { every other day, } \\
\text { alternating with prednisolone ( } 0.5 \text { or } 1 \text { mg/kg). Prednisolone was } \\
\text { continuously reduced down to } 0.5 \mathrm{mg} / \mathrm{kg} \text { every third day, then } \\
\text { once a week and later withdrawn if clinically improving } \\
\text { Two dogs were treated initially with meloxicam } 0.1 \text { mg/kg once } \\
\text { daily. One dog was put on prednisolone treatment after } \\
\text { relapsing, while the other was treated with meloxicam only }\end{array}$ \\
\hline Study design: & Retrospective single centre case series \\
\hline Outcome studied: & $\begin{array}{l}\text { Response to treatment and side effects of long-term glucocorticoid } \\
\text { steroid therapy } \\
\text { Subjective: } \\
\text { - } \quad \text { Long term follow-up of 8-34 months; for } 7 \text { dogs this was longer } \\
\text { than } 18 \text { months } \\
\text { - } \quad \text { Final examination } 2-8 \text { months after treatment terminated, } \\
\text { regularly contacted thereafter via telephone } \\
\text { Objective: } \\
\text { - CBC, biochemistry and CSF analysis at 1-3month intervals } \\
\text { - } \quad \text { Relapse of cases demonstrated by recurrence of clinical signs } \\
\text { and abnormal CSF analysis } \\
\text { - Results of clinical examination and CSF analysis at follow-up at } \\
18 \text { months }\end{array}$ \\
\hline $\begin{array}{l}\text { Main findings: } \\
\text { (relevant to PICO question): }\end{array}$ & $\begin{array}{l}\text { - Side effects included poly uria and poly dipsia }(n=7) \text {, } \\
\text { polyphagia }(n=6) \text {, urinary tract infection }(n=3), \\
\text { hyperpigmentation, alopecia, Gastrointestinal signs and }\end{array}$ \\
\hline
\end{tabular}




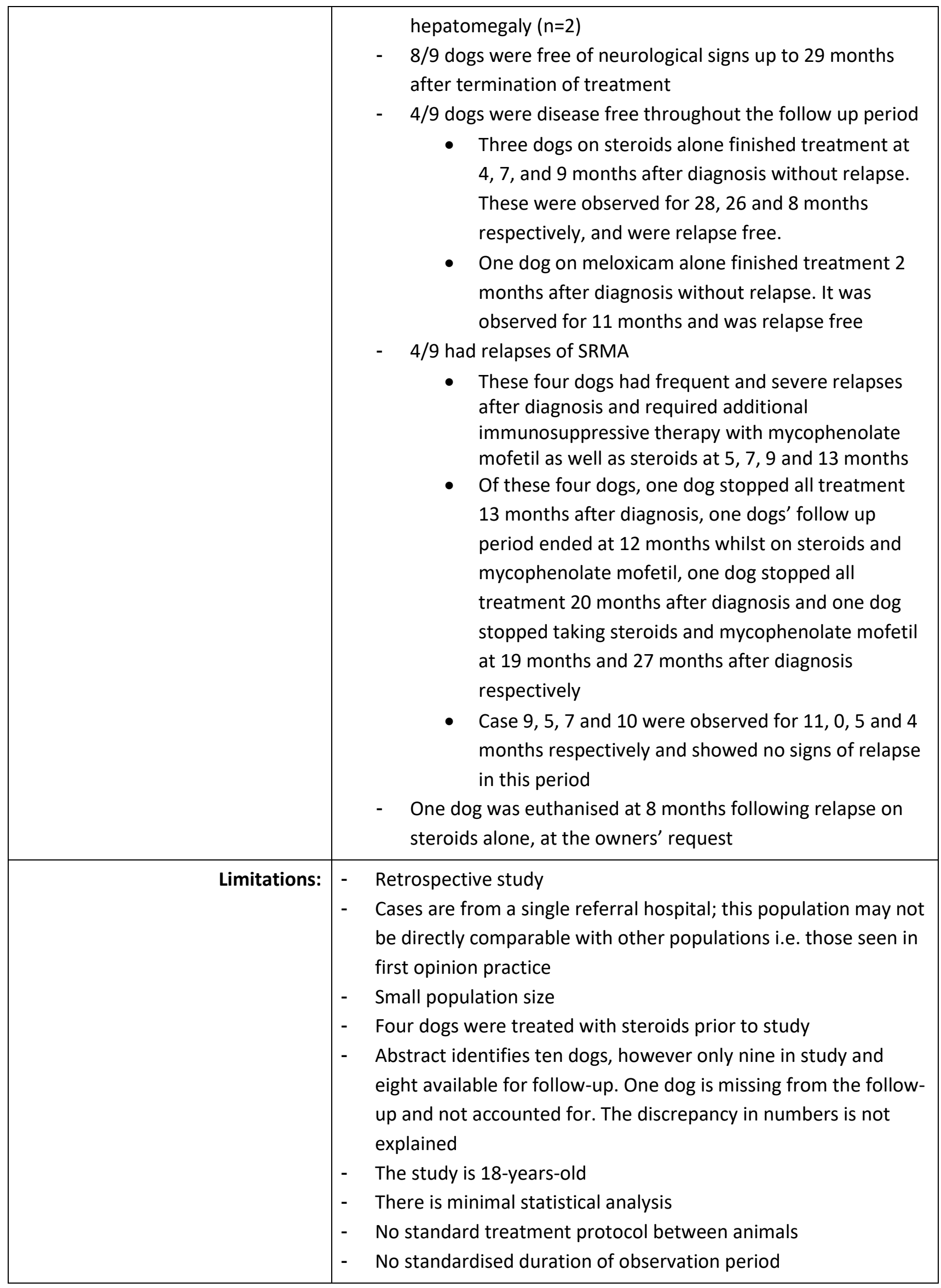

Lowrie et al. (2009) 


\begin{tabular}{|c|c|}
\hline Population: & $\begin{array}{l}\text { Client owned dogs with clinically confirmed SRMA presenting to the } \\
\text { small animal neurology service at University of Glasgow Small } \\
\text { Animal Hospital (UGSAH) between May } 2006 \text { - May } 2008\end{array}$ \\
\hline Sample size: & 20 dogs \\
\hline Intervention details: & 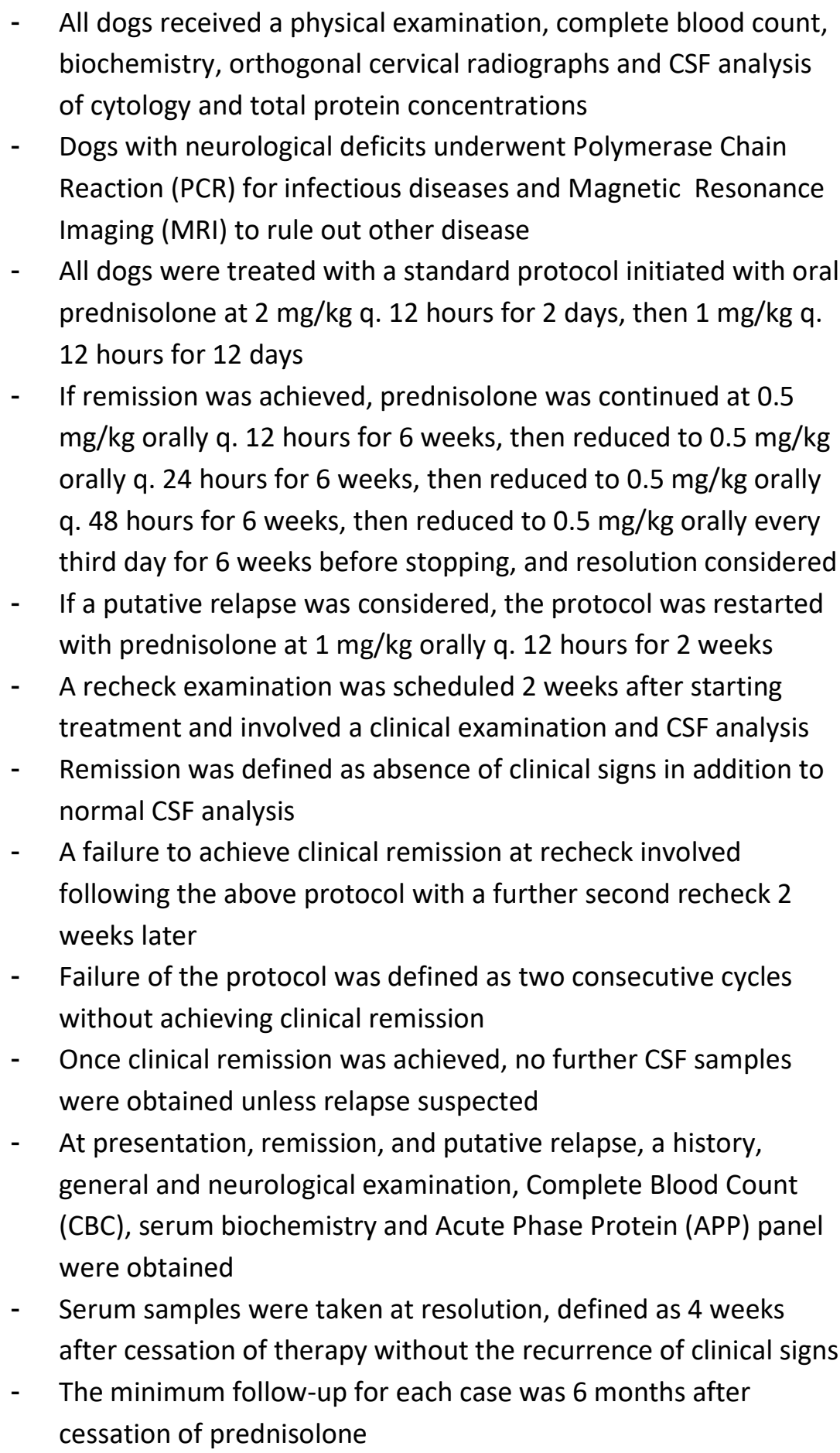 \\
\hline Study design: & Prospective single centre case series \\
\hline Outcome studied: & $\begin{array}{l}\text { Response to therapy, long term outcome and expression of potential } \\
\text { disease markers of SRMA as potential diagnostic indicators } \\
\text { Objective: } \\
\quad-\quad \text { CBC, biochemistry and CSF analysis at presentation, }\end{array}$ \\
\hline
\end{tabular}




\begin{tabular}{|c|c|}
\hline & $\begin{array}{l}\text { remission ( } 2 \text { weeks into treatment) and resolution ( } 4 \text { weeks } \\
\text { after cessation of treatment) }\end{array}$ \\
\hline $\begin{array}{l}\text { Main findings: } \\
\text { (relevant to PICO question): }\end{array}$ & $\begin{array}{l}\text { - All } 20 \text { dogs responded to the } 6 \text { month course of prednisolone } \\
\text { therapy } \\
\text { - Four out of } 20 \text { dogs were suspected of suffering putative } \\
\text { relapses with } 1 \text { dog having two separate episodes All four dogs } \\
\text { suspected of relapsing remained on treatment protocol and } \\
\text { increased prednisolone dose as described, resulted in resolution } \\
\text { of clinical signs with a } 6 \text { month follow-up period } \\
\text { - Prednisolone monotherapy was successful in achieving full } \\
\text { remission in } 20 / 20 \text { affected dogs, with an in protocol relapse } \\
\text { rate of } 20 \% \text { ( } 4 / 20 \text { dogs) } \\
\text { - Suggests relapse has a propensity to occur on treatment and not } \\
\text { after cessation of treatment } \\
\text { - The described therapy resulted in disease free post treatment } \\
\text { interval of at least } 6 \text { months }\end{array}$ \\
\hline Limitations: & $\begin{array}{l}\text { - Small population size } \\
\text { - Cases are from a single referral centre; this population may not } \\
\text { be directly comparable with other populations i.e. those seen in } \\
\text { first opinion practice }\end{array}$ \\
\hline
\end{tabular}

\section{Appraisal, application and reflection}

The available evidence was split between a retrospective case series and two prospective case series. A retrospective case series is low on the hierarchy of evidence and therefore taking a meaningful conclusion clinically from its results is difficult. Case series studies also have a high likelihood of bias.

All papers suffered from a small sample size and are focused on a population of animals attending a referral centre rather than general practice.

There was standardisation across all papers regarding diagnosis of SRMA; all cases were diagnosed based on clinical and neurological examination, CBC and serum biochemistry as well as CSF analysis. Select cases underwent further ancillary testing such as EEG and EMG (Tipold \& Jaggy, 1994), and MRI and infectious disease PCR (Lowrie et al., 2009).

There were confounding variables in Cizinauskas et al. (2000); four dogs were pre-treated with steroids prior to inclusion in the study, there was no defined follow-up period for these cases, and only three dogs received steroid monotherapy. Pretreatment with steroids was an exclusion criterion of Lowrie et al. (2009). A standardised treatment protocol for both relapses and follow-up were defined in Lowrie et al. (2009), however Tipold \& Jaggy (1994) did not detail a treatment protocol for relapse.

It appears from the available literature that a 6 month tapering steroid monotherapy protocol as per Lowrie et al. (2009) is effective at controlling clinically confirmed SRMA and resulted in a 6-month disease free posttreatment interval. A similar standardised 6 month treatment protocol was suggested by Tipold \& Jaggy (1994) which described a 4 year disease free period post-treatment, however details of how follow-up data was obtained is lacking.

It is difficult to draw meaningful conclusions from Cizinauskas et al. (2000) due to the retrospective nature, small sample size and confounding variables. Both prospective studies were based on a small sample size from a referral population, and Tipold \& Jaggy (1994) is a 23-year-old paper.

The available evidence, however, is limited and would benefit from studies of a higher power i.e. prospective, randomised, blinded studies, before a definitive recommendation of treatment duration can be made. 


\begin{tabular}{|c|c|}
\hline \multicolumn{2}{|l|}{ Search Strategy } \\
\hline $\begin{array}{r}\text { Databases searched, and dates } \\
\text { covered: }\end{array}$ & $\begin{array}{l}\text { The search was applied to } \\
\text { CAB abstracts via the Ovid platform, covering } 1973 \text { to } 2018 \text { week } 40 \\
\text { Medline via the Ovid platform from } 1946 \text { to } 2018\end{array}$ \\
\hline Search terms: & $\begin{array}{l}\text { ((dog or dogs or canine* or canid* or bitch*) AND (steroid } \\
\text { responsive meningitis-arteritis or steroid responsive meningitis } \\
\text { arteritis or SRMA)) }\end{array}$ \\
\hline Dates searches performed: & Friday 11 October 2018 \\
\hline
\end{tabular}

\section{Exclusion / Inclusion Criteria}

Exclusion: Single case reports, duplicate papers, book chapters, conference proceedings, articles where the full text was not available in English or able to be located, or articles not relevant to the PICO question.

Inclusion: Articles published between 1946 - present, articles in English and relevant to the PICO, articles with more than one animal, articles that used steroids as the only immunosuppressive.

\begin{tabular}{|c|c|c|c|c|c|}
\hline \multicolumn{6}{|c|}{ Search Outcome } \\
\hline Database & $\begin{array}{c}\text { Number of } \\
\text { results }\end{array}$ & $\begin{array}{l}\text { Excluded - } \\
\text { not relevant } \\
\text { to the PICO }\end{array}$ & $\begin{array}{l}\text { Excluded - single case } \\
\text { report/book } \\
\text { chapter/conference } \\
\text { proceeding }\end{array}$ & $\begin{array}{c}\text { Excluded - Not } \\
\text { available in } \\
\text { English }\end{array}$ & $\begin{array}{c}\text { Total relevant } \\
\text { papers }\end{array}$ \\
\hline $\begin{array}{l}\text { CAB } \\
\text { Abstracts }\end{array}$ & 74 & 51 & 16 & 4 & 3 \\
\hline Medline & 53 & 44 & 6 & 0 & 3 \\
\hline \multicolumn{5}{|c|}{ Total relevant papers when duplicates removed } & 3 \\
\hline
\end{tabular}

\section{CONFLICT OF INTEREST}

The author declares no conflicts of interest. 


\section{REFERENCES}

1. Tipold, A. and Jaggy, A. (1994) 'Steroid responsive meningitis-arteritis in dogs: Long-term study of 32 cases', The Journal of small animal practice. Wiley/Blackwell (10.1111), 35(6), pp. 311-316.

DOI: https://doi.org/10.1111/j.1748-5827.1994.tb03293.x

2. Cizinauskas, S., Jaggy, A. and Tipold, A. (2000) 'Long-term treatment of dogs with steroid-responsive meningitis-arteritis: clinical, laboratory and therapeutic results', Journal of Small Animal Practice. Wiley/Blackwell (10.1111), 41(7), pp. 295-301. DOI: https://doi.org/10.1111/i.17485827.2000.tb03205.x

3. Lowrie, M., Penderis, J., McLaughlin, M., Eckersall, P. D. and Anderson, T. J. (2009) 'Steroid Responsive Meningitis-Arteritis: A Prospective Study of Potential Disease Markers, Prednisolone Treatment, and Long-Term Outcome in 20 Dogs (2006-2008)', Journal of Veterinary Internal Medicine, 23(4), pp. 862870. DOI: https://doi.org/10.1111/j.1939-1676.2009.0337.x 


\section{EVIIDEFeE

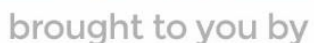 \\ RCVS KNOWLEDGE}

\section{Intellectual Property Rights}

Authors of Knowledge Summaries submitted to RCVS Knowledge for publication will retain copyright in their work, and will be required to grant RCVS Knowledge a non-exclusive license of the rights of copyright in the materials including but not limited to the right to publish, re-

publish, transmit, sell, distribute and otherwise use the materials in all languages and all media throughout the world, and to license or permit others to do so.

\section{Disclaimer}

Knowledge Summaries are a peer-reviewed article type which aims to answer a clinical question based on the best available current evidence. It does not override the responsibility

of the practitioner. Informed decisions should be made by considering such factors as individual clinical expertise and judgement along with patient's circumstances and owners' values. Knowledge Summaries are a resource to help inform and any opinions expressed within the Knowledge Summaries are the author's own and do not necessarily reflect the view of the RCVS Knowledge. Authors are responsible for the accuracy of the content. While the

Editor and Publisher believe that all content herein are in accord with current recommendations and practice at the time of publication, they accept no legal responsibility

for any errors or omissions, and make no warranty, express or implied, with respect to material contained within.

For further information please refer to our Terms of Use.

RCVS Knowledge is the independent charity associated with the Royal College of Veterinary Surgeons (RCVS). Our ambition is to become a global intermediary for evidence based veterinary knowledge by providing access to information

that is of immediate value to practicing veterinary professionals and directly contributes to evidence based clinical decision-making.

\section{https://www.veterinaryevidence.org/}

RCVS Knowledge is a registered Charity No. 230886.

Registered as a Company limited by guarantee in England and Wales No. 598443.

Registered Office: Belgravia House, 62-64 Horseferry Road, London SW1P 2AF

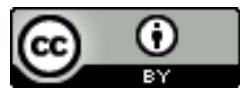

This work is licensed under a Creative Commons Attribution 4.0 International License. 